\title{
Contamination of sediments in the floodplain wetlands of the lower uMngeni River, Kwa-Zulu Natal, South Africa
}

\author{
Samantha Naidoo ${ }^{1}$, Srinivasan Pillay ${ }^{2}$, Ajay Bissessur ${ }^{3}$, \\ HARI BALlabH ${ }^{2, *}$ (D) and DELON NAICKER ${ }^{3}$ \\ ${ }^{1}$ Council for Scientific and Industrial Research, King George Avenue, Durban, South Africa. \\ ${ }^{2}$ School of Agricultural, Earth and Environmental Sciences, University of KwaZulu-Natal, Westville Campus, \\ Durban 4000, South Africa. \\ ${ }^{3}$ School of Chemistry and Physics, University of KwaZulu-Natal, Westville Campus, Durban 4000, South Africa. \\ ${ }^{*}$ Corresponding author.e-mail: ballabh2228@gmail.com
}

MS received 24 October 2016; revised 9 May 2017; accepted 10 August 2017; published online 29 March 2018

This study describes the geochemical and physico-chemical characterization of contaminant status of six wetlands of the lower uMngeni River floodplain, KwaZulu-Natal Province, South Africa. At all sites, organic matter content, calcium carbonate and metal concentrations were highest within the finesediment dominated surface laminae, decreasing with depth. Exceptions were displayed by arsenic (As), nickel $(\mathrm{Ni})$ and vanadium $(\mathrm{V})$, presumed to be derived from normal geochemical processes. Geochemical indicies indicated high contamination factors for lead $(\mathrm{Pb})$ and $\mathrm{V}$, pointing to moderate anthropogenic metal pollution contribution. Most conspicuous are the contamination high factors for $\mathrm{Pb}$ across most sites. Fe and $\mathrm{Pb}$ contamination is ubiquitous in all surface laminae, with contamination factors being either border-line, moderate or of high contamination. Enrichment factors for As, Mn and P at site S6 indicate possible anthropogenic sources. The data also shows a possibility of anthropogenic input of $\mathrm{P}$ and $\mathrm{Zn}$ at site S3. Apart from the enrichment factors established for Ni across all sites, all other metals indicate some degree of enrichment. A range of variable results for the mid to deeper laminae are indicative of natural processes with some human influence. Results of ANOVA confirm the above. Principal component analysis reveals a $46.4 \%$ variance from component 1 elements (Al, $\mathrm{Ca}, \mathrm{Cr}, \mathrm{Cu}, \mathrm{Fe}$, $\mathrm{Mg}, \mathrm{Mn}$ and $\mathrm{Zn}$ ) and a $17.8 \%$ variance from component $2(\mathrm{Al}, \mathrm{Cu}$ and $\mathrm{Fe}$ ). Given the rapid rate of development in this region, the protection of these floodplain wetlands must receive high conservation priority from the local municipality.

Keywords. Sediment core; contamination; enrichment.

\section{Introduction}

Coastal regions contain a multitude of natural resources and therefore epitomise hubs of human activity in both developed and developing countries alike (Cobelo-García and Prego 2004). Microecosystems, such as wetlands, which were once commonalities of coastal areas, are subjected to progressive degradation and destruction over time by nations in pursuit of economic growth and development (Vitousek et al. 1997; Rana et al. 2016). The reduction of previously large functioning wetlands to scattered remnants is an obvious manifestation of unrestrained human influence in the past, and in many cases, its persistence in the present day (Walmsley 1992). Although 
past perceptions of wetlands have been largely abandoned and increasing efforts are being made by government and non-governmental organisations to manage and protect wetland environment, development continues to pose a real and perilous threat to the health of existing wetland ecosystems (Gren et al. 1994).

The mounting pressure on wetland resources and functioning; elicited by increased urbanisation, injudicious agricultural practices and industrialisation, is further compounded by surges in human population and the concentration of anthropogenic activity in close proximity to wetland features (Brijlal 2005; Niu et al. 2015). Densely urbanised localities along the coast act as significant waste- and chemical-producing areas that contribute largely to the enrichment of wetland sediments by contaminants such as metals that typically comprise effluent discharges from industries, and leachate from sources of municipal waste and cultivated land (Cobelo-García and Prego 2003; Nabulo et al. 2008).

The correlation between the health and integrity of an environment and the sustainability of its soil ecosystem has been well documented. Sediment pollution is known to decrease soil quality and alter ecosystems in ways that prove detrimental to their biotic constituents and dependents (Ayeni et al. 2010). The danger of metals being present in wetlands in quantities exceeding those deposited via natural processes is primarily associated with the high potential for their release from sediments into surrounding waters subsequent to changes in prevailing physical and chemical characteristics in the water column (Kotze 2000). The implications are unattractive from an ecosystem health perspective given the reputed ability of metals to bio-accumulate and bio-magnify in wetland organisms, the consequences of which prove detrimental to affected biota as well as reliant human populations (Nomaan et al. 2012). The importance of maintaining acceptable soil quality in wetland ecosystems, and in other ecosystems alike, therefore arises from the need to maintain the capacity of sediments to sustain plant and animal productivity, provide refuge for dependent biota, and thereby support ecosystem functioning and human well-being (Karlen et al. 1997; Ahmed et al. 2015).

The effectiveness of utilising sediments as a sensitive indicator to monitor the level of metal pollution and trace contamination sources has been largely recognised, accepted by experts and the larger scientific community (Soares et al. 1999; Harikumar et al. 2009). This realised efficacy is based on the ability of sediments to promptly adsorb and accumulate metals carried by the above-flowing water, allowing for a greater degree of accuracy in metal detection than the employment of alternative analysis methods, irrespective of water level at the given time (Soares et al. 1999). The adsorption capacity of wetland sediments, however, is highly variable based on the physical and chemical properties of sediment, principally, particle size and organic matter content (Sheoran and Sheoran 2006). Trace metals, for instance, naturally display a higher affiliation for finer-grained sediment, and sediment constituting a higher percentage of organic matter (Khechfe 1997). Furthermore, sediment cores have been useful in studying the behaviour of metals and broadly reflecting the sediment history, and thus the contamination history of an area (Harikumar et al. 2009).

In order to determine whether the concentration of detected metals in sediments are of natural or anthropogenic origin, and establish their level of acceptability regarding their contribution towards maintaining optimum functionality of the wetland, it is essential that results obtained are compared with standard background values for the region or geological type (Martínez-Carballo et al. 2007 and Chenhall et al. 2004 in Sukdeo et al. 2011). 'Geochemical backgrounds' or 'Clarke values' are values that indicate the normal quantity of each metal within a specific geographic location characterised by a certain geological pattern, and are preferentially used for comparative purposes as standard background values with the aim of identifying anomalies and thus deviations from the 'norm' (Bhuiyan et al. 2010).

This study was aimed at determining and comparing the concentration of specific potential metal contaminants in the soils of six selected sites of the floodplain wetlands of the lower uMngeni River, a region exposed to significant development in recent years.

\section{Study area}

The floodplain wetlands along the lower uMngeni River have become increasingly exposed to human activities (Water Research Commission 2002). It is located just north of the CBD of the city of Durban, an area that has experienced rapid 
development in the past decade (Water Research Commission 2002). The uMngeni River originates in the foothills of the Drakensberg Mountains at an elevation of approximately $2000 \mathrm{~m}$ above sea level from where it traverses approximately $255 \mathrm{~km}$ before entering the Indian Ocean to the north of Durban Harbour (Van der Zel 1975; Cooper 1993). The geology of the catchment is largely belongs to the Karoo system of sedimentary rocks with sandstones of the Tarkastad and Estcourt formation, and shales of the Volksrust and Pietermaritzburg formations outcropping at varying altitudes (Rural Development Services 2002). The input of heavy metals into the lower uMngeni wetlands may be attributed to a multitude of catchment land uses, including commercial and small-scale subsistence farming, industrial activity, urban development, formal and informal settlements (Brijlal 2005; South Durban Community Environmental Alliance 2011). Considering the importance of the uMngeni River system in providing water to the greater Durban and Pietermaritzburg metropolitan communities in Kwa-Zulu Natal, the value of floodplain wetlands occurring along the channel should not be underestimated, as they may well serve to perform distinct functions that facilitate the creation and maintenance of favourable conditions in the adjacent river (Kotze 2000; Dickens et al. 2003) and the estuary further downstream.

\section{Materials and methods}

\subsection{Wetland sediment cores}

Sediment cores were collected from each of six identified floodplain wetlands along the uMngeni River as illustrated in figure 1 . The sites were selected based on factors of accessibility, the pliability of the soil for penetration, and their location within three distinctly differing land use regions, namely residential, industrial and estuarine. This was done with the intention of enabling comparison between the results attained for each region to infer deductions related to the potential source of pollutants.

Sediment cores were collected from the selected sites in November 2011. The cores were collected by establishing a transect line across the selected wetlands from approximately $30 \mathrm{~m}$ up-bank towards the river channel, along which between one and three cores were collected at equidistant intervals. At sites S3 and S5, two cores were collected, while only one core was collected at S1, S2, S4 and
S6 respectively due to a visible narrowing of the wetlands and the presence of resistant soils. Core depths reached $1-1.8 \mathrm{~m}$, and varied according to the thickness of soil horizons and depth to the water table in each case. Land uses adjacent to sampling sites were $\mathrm{S} 1$ - informal housing and light industry; S2 - sports fields; S3 - golf course; S4 - light industry; S5 and S6 - broad wetland with undisturbed vegetation, a grassed buffer zone of approximately $50 \mathrm{~m}$ bordered by industries.

The cores were collected using a $40 \mathrm{~mm}$ diameter poly-vinyl-compound (PVC) pipe with the assistance of a hand auger. On extraction of the pipe containing the sediment core, the pipe was appropriately labelled indicating site and transect number, date and time. GPS co-ordinates of each site were recorded and both ends of the pipe were securely sealed.

The cores were split longitudinally in half and sediment laminae carefully logged based on compositional characteristics, such as texture, colour, lamination and organic material. Two sub-samples were taken from each layer based on texture and composition, one for the determination of physical properties and the other for chemical analysis. Soil moisture content was determined by drying; organic matter content by both ignition loss and the Walkley-Black method and calcium carbonate content by ignition loss.

The standard dry sieving method was utilised for grain size determination using a Retsch ${ }^{\circledR}$ sieve shaker. Elemental concentrations of aluminium $(\mathrm{Al})$, calcium $(\mathrm{Ca})$, chromium $(\mathrm{Cr})$, copper $(\mathrm{Cu})$, iron $(\mathrm{Fe})$, lead $(\mathrm{Pb})$, magnesium $(\mathrm{Mg})$, manganese $(\mathrm{Mn})$, nickel $(\mathrm{Ni})$, phosphorous $(\mathrm{P})$, sulphur $(\mathrm{S})$, vanadium $(\mathrm{V})$ and zinc $(\mathrm{Zn})$ were detected using inductively coupled plasma-optimal emission spectroscopy (ICP-OES), ion chromatography and flame photometry as prescribed by Skoog and West (1982). Analysis of Variance (ANOVA) was used to assess the variance of elemental concentrations at the sites and of the geochemical indices. Principal Component Analysis (PCA) was used to gain insight into the contribution of elements to contamaination and subsequent pollution loading at each site.

\subsection{Assessing contamination using pollution indices}

The level of sediment contamination by metals can be assessed by specific pollution indices. In this study, the contamination factor and enrichment 


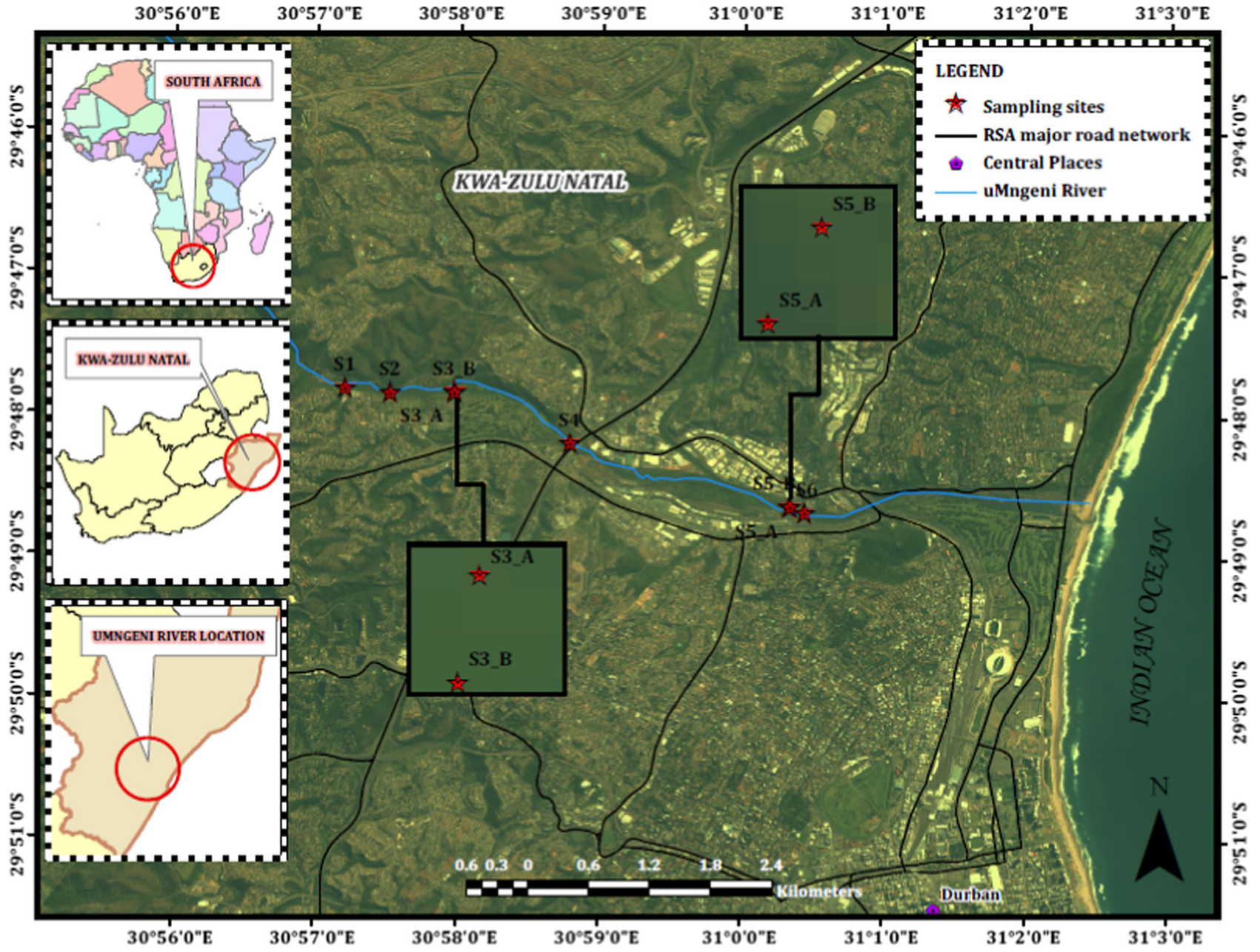

Figure 1. Map of the core sampling sites along the floodplain wetlands of the uMngeni River.

factor were calculated and 'Clarke values' for sedimentary rocks, the dominant catchment geology, were utilised as background concentrations (Martinez et al. 2007). Contamination factors are used to determine whether measured concentrations of metals in a sediment sample are of natural or anthropogenic origin, and are calculated as:

$$
\mathrm{CF}=\frac{[\text { Concentration of element in the sediment }]}{[\text { Background value of element }]}
$$

Contamination factors range in value from 0 to 6 , with a value of zero indicating no contamination and a value of six, signifying strong contamination (Bhuiyan et al. 2010). More specifically, values less than 1 imply low contamination, values between 1 and 3 imply moderate contamination, and values between 3 and 6 indicate significant contamination (Harikumar and Jisha 2010). Enrichment factors are used to ascertain the abundance of a specific metal in a sediment sample in relation to the average concentration in the earth's crust (Harikumar and Jisha 2010).

This calculation can be expressed as equation (2) below:

$\mathrm{EF}=\frac{[\text { Concentration of element }][\text { Concentration of } \mathrm{Fe}]}{[\text { Clarke value of element }][\text { Clarke value of } \mathrm{Fe}]}$

In the above equation, [Concentration element] refers to the mean concentration of the metal of interest (ppm), [Concentration Fe] is the mean concentration of $\mathrm{Fe}$ in the sediment sample (ppm), [Clarke element] is the Clarke value of the metal of interest (ppm) and [Clarke Fe] is the Clarke value of iron (ppm). Iron was used as the reference element for geochemical normalisation due to its geochemical similarity to many other trace metals, its natural high concentrations and the usual uniformity of its natural concentration (Bhuiyan et al. 2010). According to Harikumar 
and Jisha (2010), values between 0.5 and 1.5 indicate metal input from natural sources, values $>1.5$ indicate possible input from anthropogenic sources, and values $>5$ imply contamination.

\section{Results and discussion}

\subsection{Physical properties of core sediments}

At all six sites, organic matter content (OMC) and calcium carbonate $\left(\mathrm{CaCO}_{3}\right)$ were highest within the first three laminae of sediment cores, then fluctuated with a generally decreasing trend for subsequent laminae. These percentages are inversely related to the sediment mean grain size (phi) calculated for each lamina such that finer mean sediment grain size contain higher percentages of OMC and $\mathrm{CaCO}_{3}$ detected within the lamina. The percentage of moisture content (MC) is also shown to be high within the first three laminae of sediment cores, as finer sediments retain more water; and high within deeper lamina due to increasing proximity to the water table.

These relationships are illustrated in figure 2(a-p). Figure 2(a, c, e, g, i, k, m and o) depicts the sediment mean grain size variations with core depth; and figure $2(b, d, f, h, j, l, n$ and $p$ ) shows the percentage $\mathrm{MC}, \mathrm{OMC}$ and $\mathrm{CaCO}_{3}$ variations with core depth at sites S1, S2, S3(T1), S3(T2), S4, S5(T1), S5(T2) and S6, respectively. The high content of fine grained material (silt and clay), and hence low sediment mean grain size (phi), in the upper laminae are to be expected in floodplain wetlands that are regularly exposed to overbank flooding. Fine material carried in suspension in flood waters covering the floodplain gradually settle out as a mud layer as floodwaters recede. There is generally a coarsening of grades with depth within such layers and this has also been detected with several of the laminae of the cores taken in this study. In general, however, it can be noted that the sediment mean grain size in laminae across all sites did not reach a phi value of 3 . The implication is that these wetlands are dominated by medium to fine silt and clay particles, which in turn suggest a high propensity for metal ion accumulation. Highest OMC was measured at site 3 located adjacent to the golf course. At this site, river morphology for accumulation of organic debris and riparian vegetation was particularly well established. Further downstream at site 5 , which is characterized by dense natural vegetation, $\mathrm{OMC}$ increases again in the first two laminae. Calcium carbonate content is low with some variability across sites. Some increases are noted at the golf course, site 3 , where considerable amounts of fertilizers are regularly applied, and at sites 5 and 6 . The latter sites are largely pristine and the observed concentrations are likely due to natural geochemical processes. In all cases, soil moisture was high in the first two to three laminae, which also increases with depth as is expected in an environment where the water table is located close to the surface.

\subsection{Chemical properties of core sediments}

Figure $3(\mathrm{a}-\mathrm{n})$ plots mean metal concentration with respect to the depth for each of the six sites. Given that the thickness of each lamina within various cores differs considerably, depths at which comparisons amongst metal levels were made were standardised. The mean metal concentrations are thus illustrated using these standardised depths. Hence, line graphs of figure 3 begin at a depth of $10 \mathrm{~cm}$ (mid-point of first segment).

Clearly, a general trend of decreasing metal concentration with increasing core depth is observed, correlating well with the vertical distribution of organic matter and fine sediment. This collates with the known high affinity of organic matter and fine sediment for adsorbing metal ions. Exceptions to the trend are displayed in concentration change of arsenic (As), nickel (Ni) and vanadium (V). At site 6, arsenic levels in the sediment increases with soil depth. Since this site contains relatively pristine wetland vegetation, with no visible sign of anthropogenic effluent contamination, the high As is presumed to be an analomous, naturally occuring concentration. The high $\mathrm{Ni}$ and $\mathrm{V}$ detected at Sites 2 and 3, respectively are presumed to be derived from normal geochemical processes and represent anomolous high natural concentrations.

Geochemical indicies using mean values of the relevant sites were used to further infer deductions relating to the anthropogenic contribution of contaminant enrichment at each of the sites. Table 1 presents the contamination factors (CF) calculated for the measured concentrations of specific elements within sediments at each sampling point. The $\mathrm{CF}$ values obtained for most elements were in the range of zero and one, indicating minimal baseline pollution of the wetlands. However, contamination factors for lead $(\mathrm{Pb})$ and 

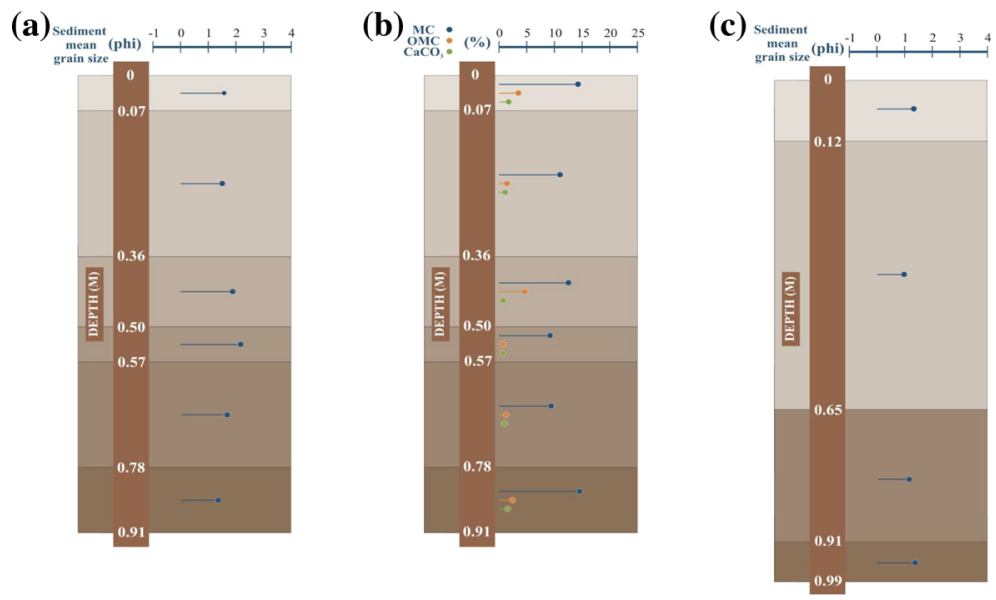

(d)

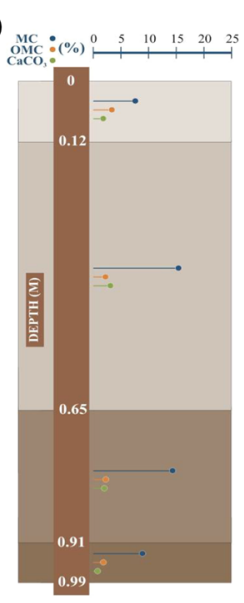

$(\mathbf{e})$
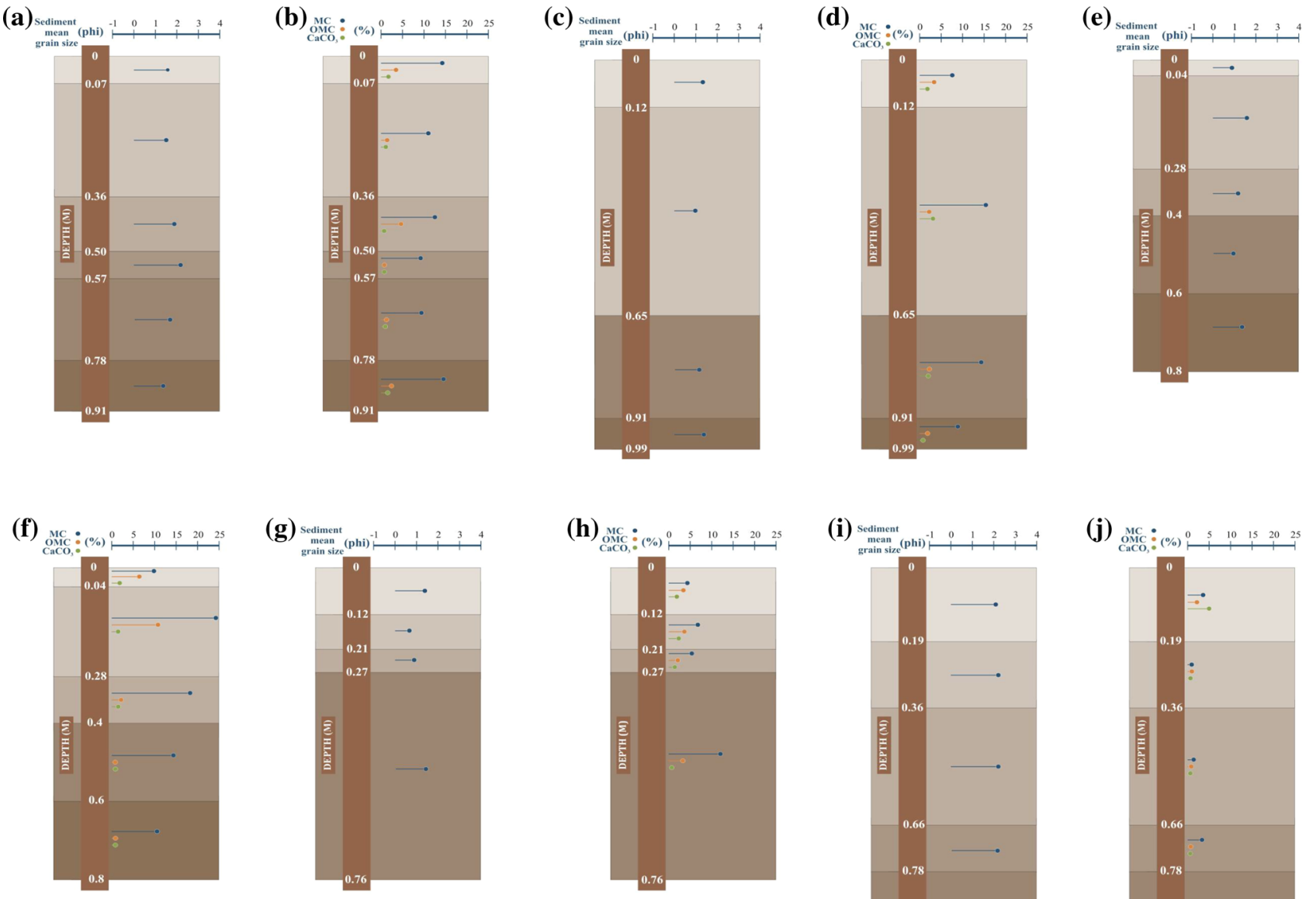

(i) $\mathrm{se}$
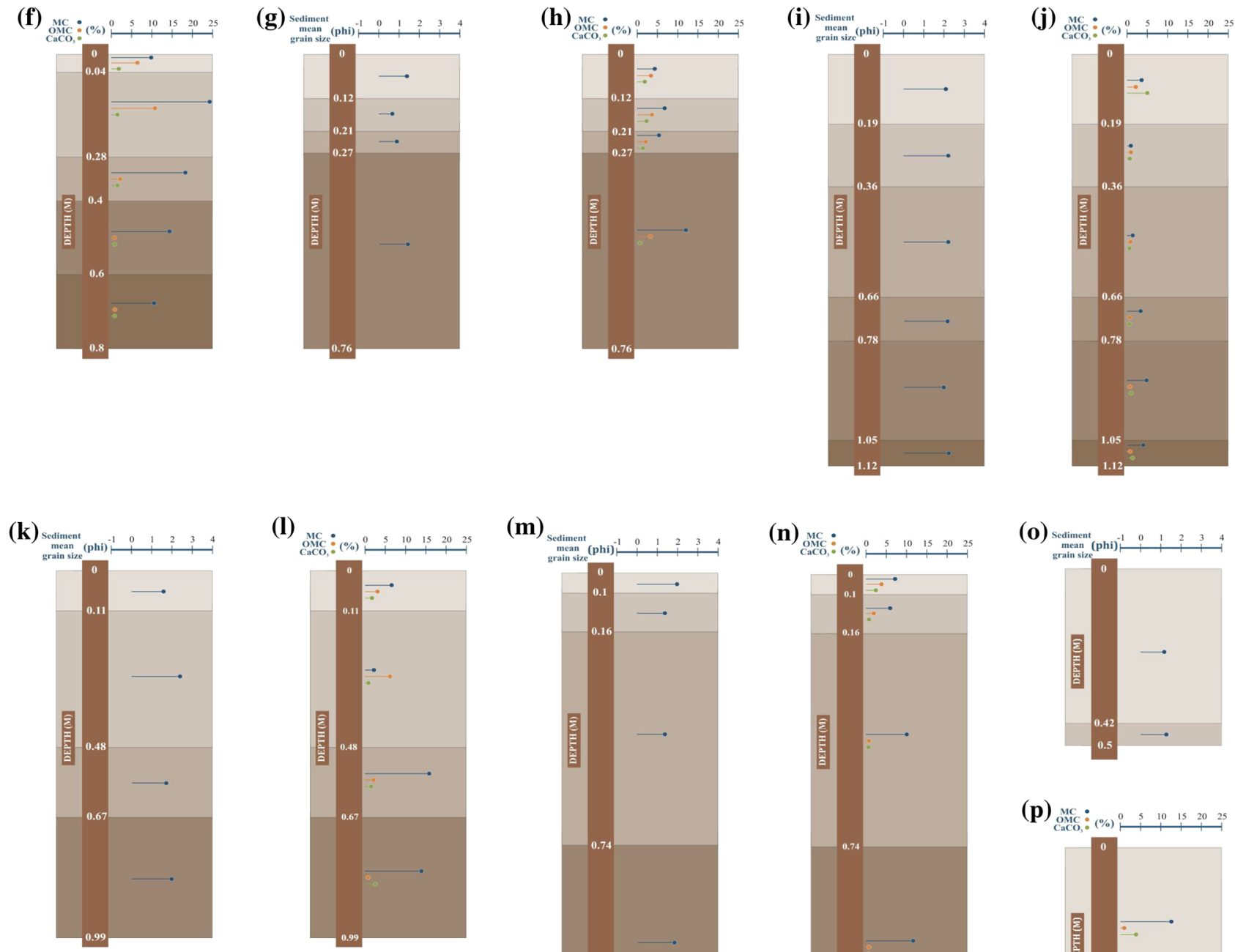

(m)

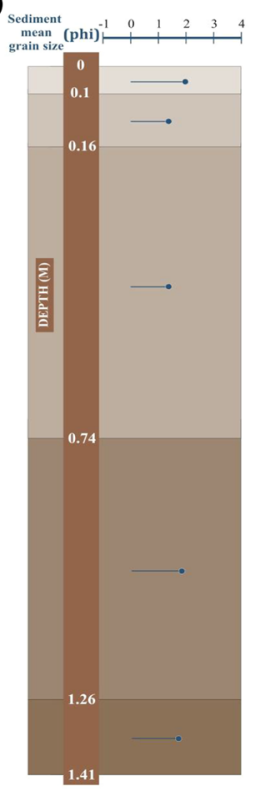

(n)

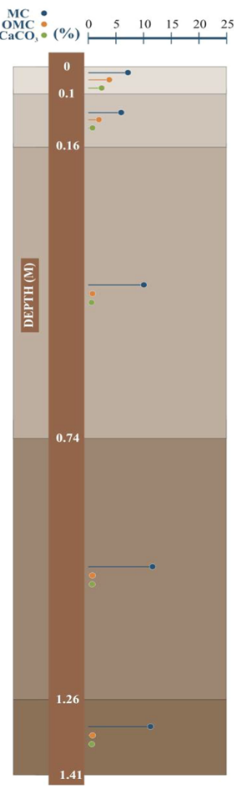

(o) s

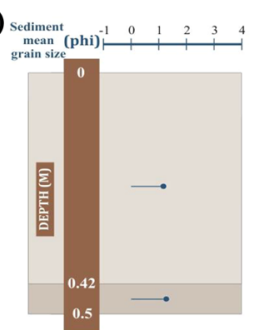

(p)

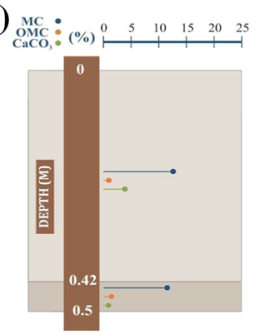

Figure 2(a-p). Sediment mean grain size (phi) in relation to percentage $\mathrm{MC}, \mathrm{OMC}$ and $\mathrm{CaCO}_{3}$ contained in core laminae at each site. 

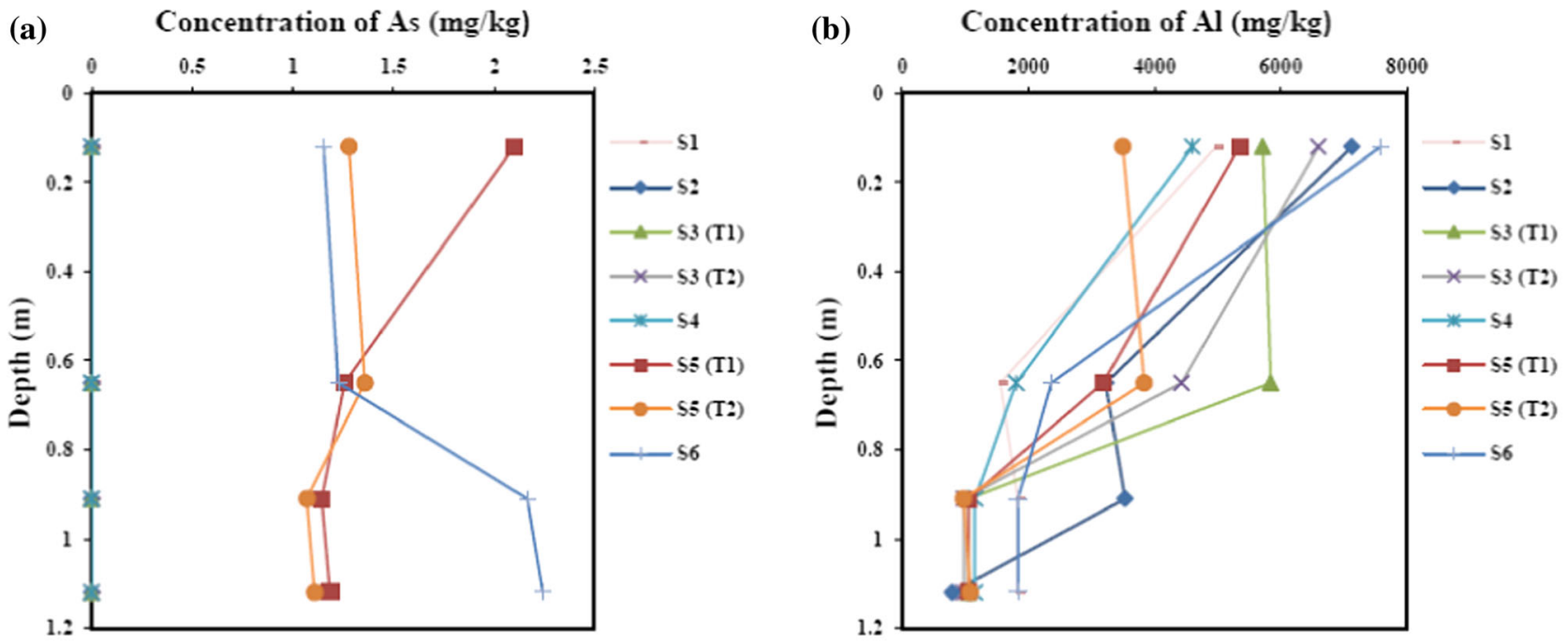

(c)

Concentration of $\mathrm{Ca}(\mathrm{mg} / \mathrm{kg})$

(d)

Concentration of $\mathrm{Cr}(\mathrm{mg} / \mathrm{kg})$
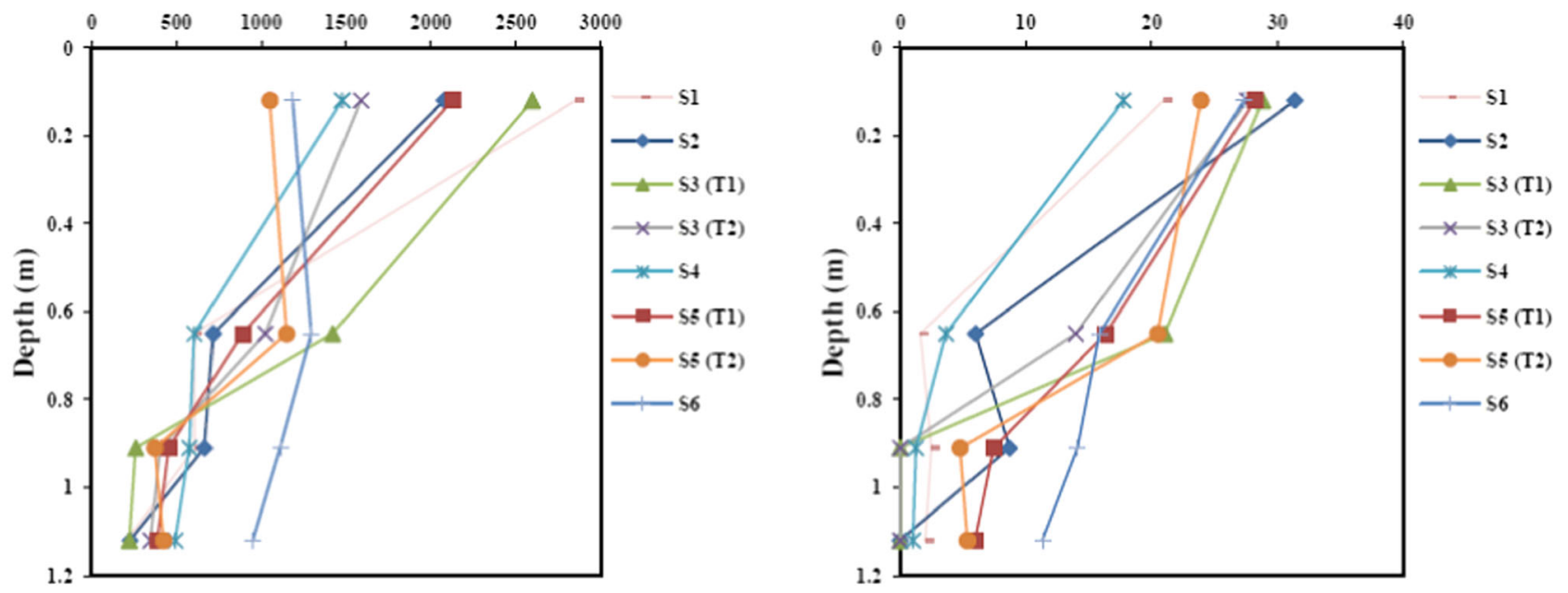

(e) Concentration of $\mathrm{Cu}(\mathrm{mg} / \mathrm{kg})$

(f)

\section{Concentration of $\mathrm{Fe}(\mathrm{mg} / \mathrm{kg})$}
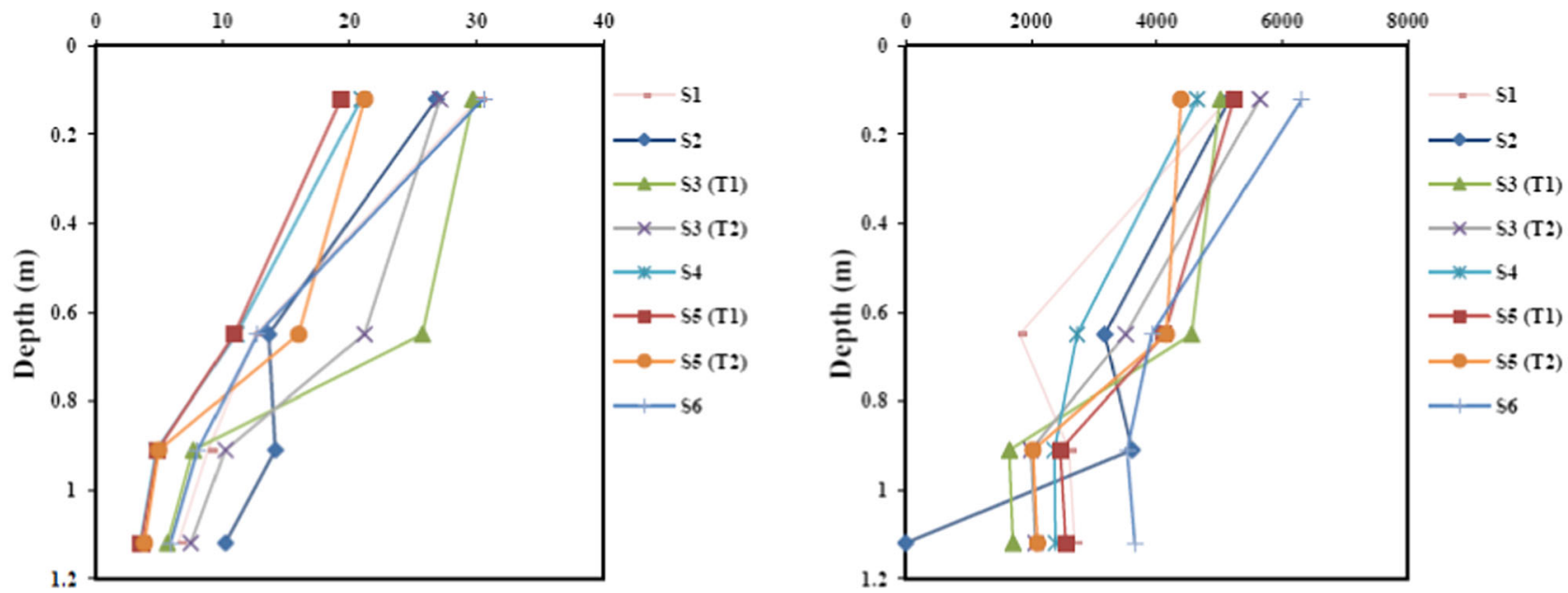

Figure $3(\mathrm{a}-\mathrm{n})$. Change of element concentrations with depth at each of the study sites. 

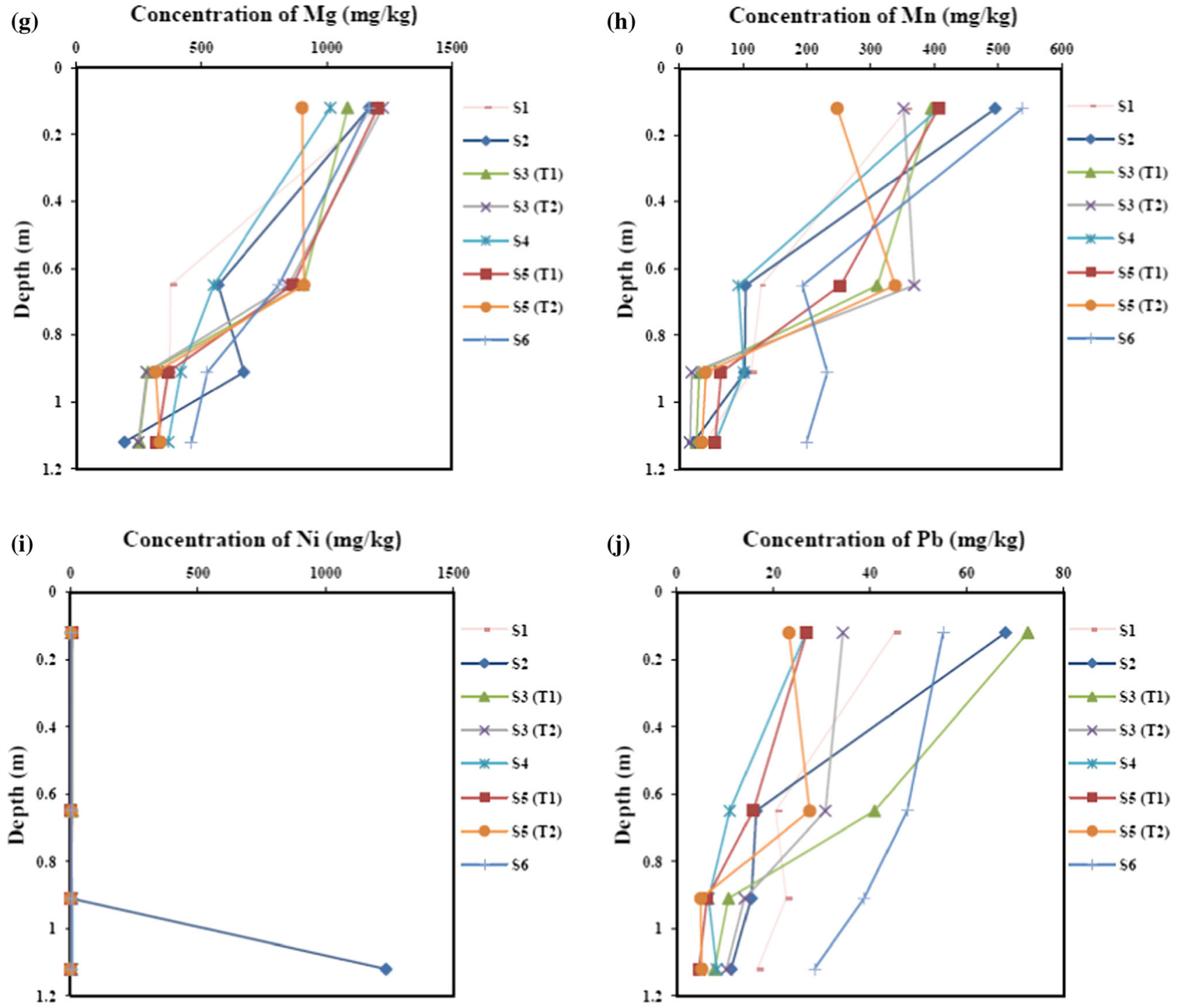

(k) Concentration of $\mathrm{P}(\mathrm{mg} / \mathrm{kg})$
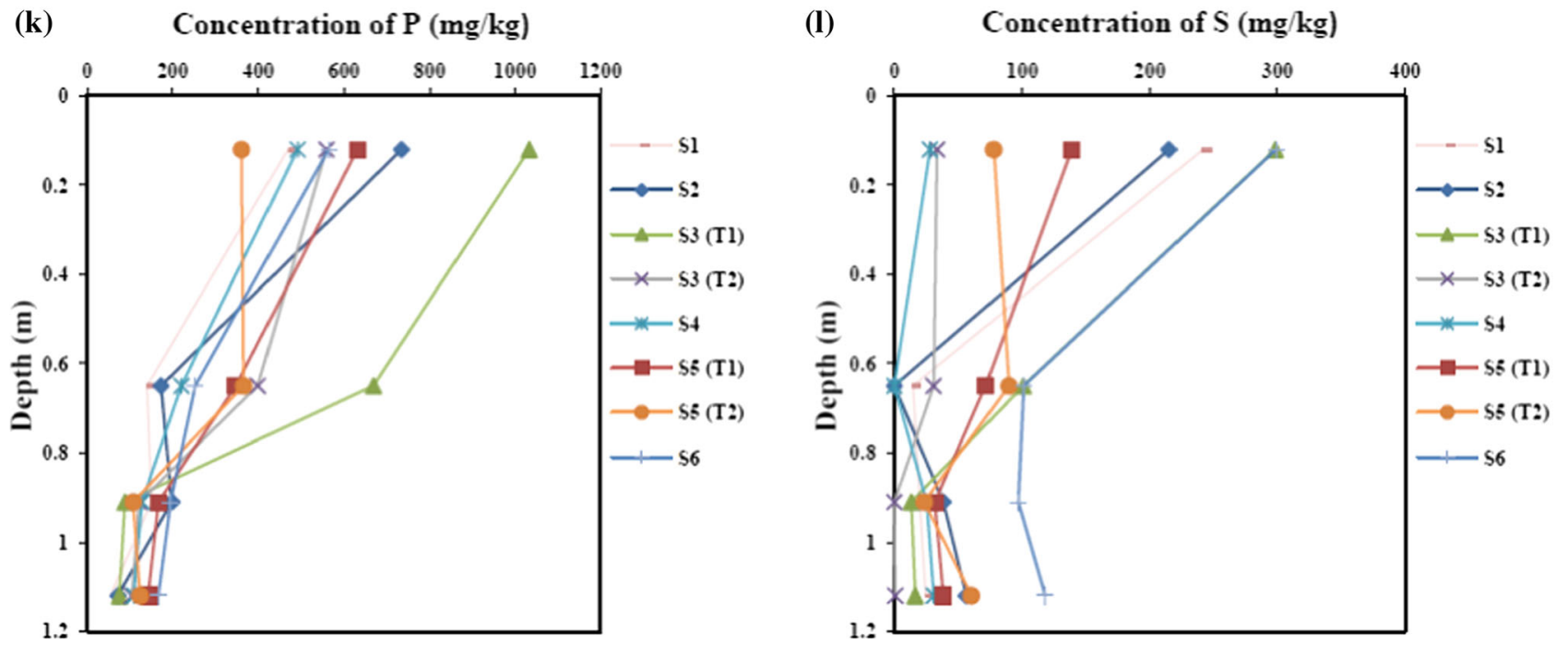

Figure 3. (Continued.) 

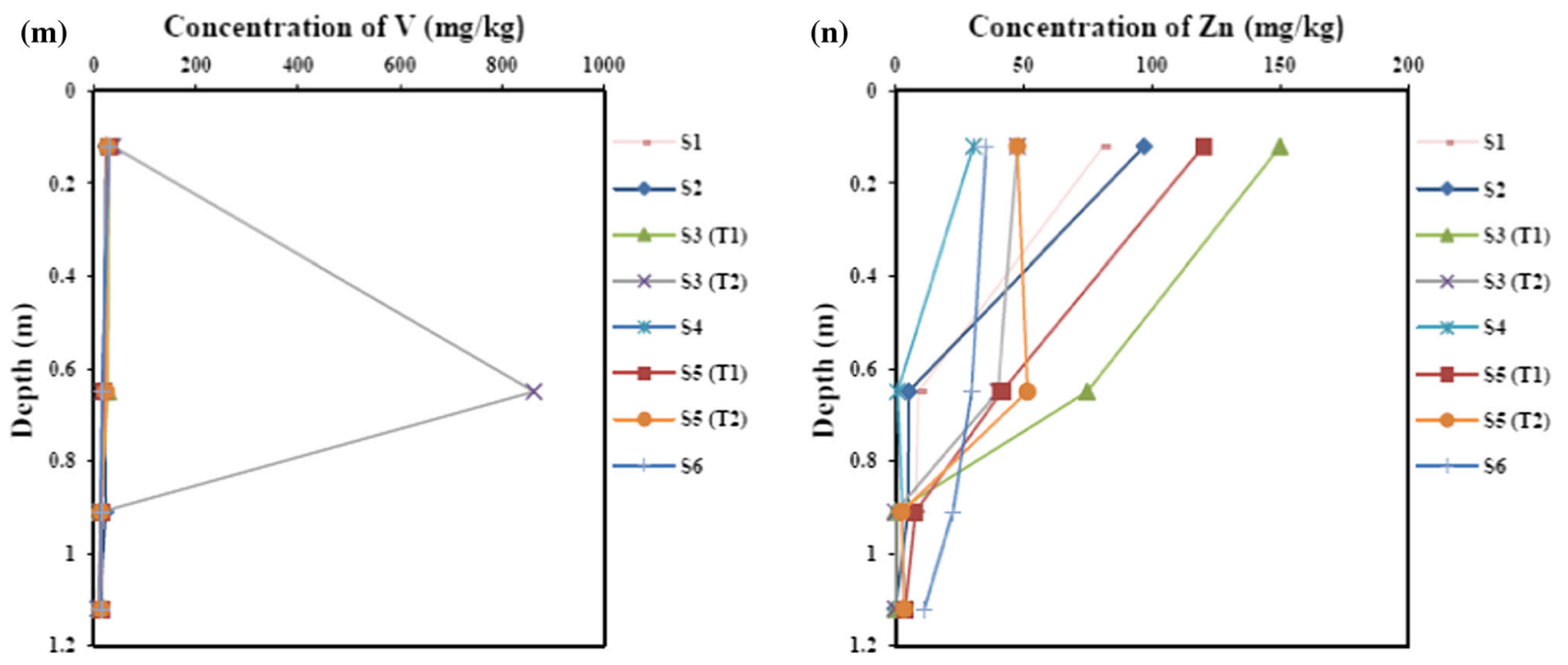

Figure 3. (Continued.)

Table 1. Contamination factor of mean concentration of elements present within sediments at each sample site.

\begin{tabular}{lrllllllll}
\hline Element & Clarke value & $\mathrm{S} 1$ & $\mathrm{~S} 2$ & $\mathrm{~S} 3(\mathrm{~T} 1)$ & $\mathrm{S} 3(\mathrm{~T} 2)$ & $\mathrm{S} 4$ & $\mathrm{~S} 5(\mathrm{~T} 1)$ & $\mathrm{S} 5(\mathrm{~T} 2)$ & $\mathrm{S} 6$ \\
\hline $\mathrm{Al}$ & 81300 & 0.031 & 0.045 & 0.042 & 0.040 & 0.027 & 0.033 & 0.029 & 0.042 \\
$\mathrm{As}$ & 5 & $\mathrm{NE}$ & $\mathrm{NE}$ & $\mathrm{NE}$ & $\mathrm{NE}$ & $\mathrm{NE}$ & 0.284 & 0.241 & 0.339 \\
$\mathrm{Ca}$ & 36300 & 0.029 & 0.025 & 0.031 & 0.023 & 0.022 & 0.027 & 0.021 & 0.031 \\
$\mathrm{Cr}$ & 200 & 0.034 & 0.058 & 0.062 & 0.052 & 0.030 & 0.072 & 0.068 & 0.086 \\
$\mathrm{Cu}$ & 70 & 0.208 & 0.231 & 0.246 & 0.236 & 0.144 & 0.138 & 0.164 & 0.205 \\
$\mathrm{Fe}$ & 50000 & 0.061 & 0.060 & 0.065 & 0.066 & 0.061 & 0.072 & 0.063 & 0.087 \\
$\mathrm{Mg}$ & 20900 & 0.027 & 0.031 & 0.030 & 0.031 & 0.028 & 0.033 & 0.029 & 0.035 \\
$\mathrm{Mn}$ & 1000 & 0.160 & 0.181 & 0.191 & 0.189 & 0.165 & 0.196 & 0.166 & 0.291 \\
$\mathrm{Ni}$ & 80 & 0.009 & 0.020 & 0.046 & 0.023 & 0.045 & 0.023 & 0.019 & 0.042 \\
$\mathrm{P}$ & 1180 & 0.172 & 0.249 & 0.379 & 0.251 & 0.201 & 0.273 & 0.203 & 0.250 \\
$\mathrm{~Pb}$ & 16 & $\mathbf{1 . 6 4 0}$ & $\mathbf{1 . 7 4 0}$ & $\mathbf{2 . 0 6 8}$ & $\mathbf{1 . 4 0 2}$ & 0.827 & 0.841 & 0.956 & $\mathbf{2 . 6 5 8}$ \\
$\mathrm{V}$ & 150 & 0.115 & 0.126 & 0.136 & $\mathbf{1 . 5 4 9}$ & 0.121 & 0.133 & 0.128 & 0.121 \\
$\mathrm{Zn}$ & 132 & 0.193 & 0.204 & 0.426 & 0.166 & 0.072 & 0.329 & 0.199 & 0.188 \\
\hline
\end{tabular}

NE: No enrichment.

vanadium $(\mathrm{V})$ exceed one at certain sites, implying moderate metal pollution derived from anthropogenic sources. Results of ANOVA confirm that, although the variances for all elements are low, the highest for this suite of metals were recorded for $\mathrm{Pb}(0.419)$ and $\mathrm{V}(0.253)$.

The contamination factor for vanadium is highest at site S3(T2) and although its source is unknown, it might be related to the ongoing fertilization and maintenance activities at the golf course. The most conspicuous, however, are the contamination factors of lead, which are shown to be high in sites 1, 2, 3 (transect 1 and 2) and 6 being most contaminated. It must also be noted that $\mathrm{Pb}$ input at sites $\mathrm{S} 4, \mathrm{~S} 5(\mathrm{~T} 1)$ and $\mathrm{S} 5(\mathrm{~T} 2)$ in particular; have shown border-line to moderate contamination levels.

Table 2 presents the highest contamination factors calculated for each lamina of sediment cores. These are compared to enrichment factors calculated using mean values displayed in table 1.

From table 2, it can be seen that the contamination factors for $\mathrm{Fe}$ and $\mathrm{Pb}$ are highest in the 1st, 2nd and 3rd laminae of each sediment core. Contamination factors for $\mathrm{Zn}, \mathrm{P}$ and $\mathrm{V}$ on the other hand are highest in the 1st and 2nd laminae, 2nd lamina, and 3rd lamina, respectively. This corresponds to the highest variance of 1.40 for $\mathrm{Pb}$ in L1; 1.96 for $\mathrm{Pb}$ in $\mathrm{L} 2$ and 17.94 for $\mathrm{V}$ in $\mathrm{L} 3$. 
Table 2. Contamination factor of particular elements present within the laminae of sediment cores at each sample site.

\begin{tabular}{lcccccccccc}
\hline Ion & Clarke value & $\mathrm{L}$ & $\mathrm{S} 1$ & $\mathrm{~S} 2$ & $\mathrm{~S} 3(\mathrm{~T} 1)$ & $\mathrm{S} 3(\mathrm{~T} 2)$ & $\mathrm{S} 4$ & $\mathrm{~S} 5(\mathrm{~T} 1)$ & $\mathrm{S} 5(\mathrm{~T} 2)$ & $\mathrm{S} 6$ \\
\hline $\mathrm{Fe}$ & 50000 & 1 & $\mathbf{1 . 0 2 8}$ & $\mathbf{1 . 0 3 5}$ & $\mathbf{1 . 0 0 5}$ & $\mathbf{1 . 1 2 9}$ & 0.930 & $\mathbf{1 . 0 4 8}$ & 0.878 & 0.785 \\
$\mathrm{~Pb}$ & 16 & 1 & $\mathbf{2 . 8 1 3}$ & $\mathbf{4 . 2 5 3}$ & $\mathbf{4 . 5 4 0}$ & $\mathbf{2 . 1 5 1}$ & $\mathbf{1 . 6 7 4}$ & $\mathbf{1 . 6 8 4}$ & $\mathbf{1 . 4 5 4}$ & $\mathbf{2 . 9 8 0}$ \\
$\mathrm{Zn}$ & 132 & 1 & 0.614 & 0.736 & $\mathbf{1 . 1 3 7}$ & 0.362 & 0.232 & 0.910 & 0.361 & 0.226 \\
$\mathrm{Fe}$ & 50000 & 2 & 0.510 & 0.636 & $\mathbf{1 . 2 9 1}$ & 0.872 & 0.429 & 0.502 & $\mathbf{1 . 3 5 3}$ & 0.706 \\
$\mathrm{~Pb}$ & 16 & 2 & $\mathbf{1 . 6 1 0}$ & $\mathbf{1 . 0 3 0}$ & $\mathbf{4 . 6 0 9}$ & $\mathbf{2 . 0 2 2}$ & 0.636 & 0.401 & $\mathbf{3 . 1 1 7}$ & $\mathbf{2 . 4 2 6}$ \\
$\mathrm{Zn}$ & 132 & 2 & 0.082 & 0.040 & $\mathbf{1 . 2 7 2}$ & 0.397 & 0.000 & 0.045 & 0.760 & 0.171 \\
$\mathrm{P}$ & 1180 & 2 & 0.134 & 0.146 & $\mathbf{1 . 2 4 6}$ & 0.486 & 0.155 & 0.129 & 0.536 & 0.165 \\
$\mathrm{~Pb}$ & 16 & 3 & $\mathbf{1 . 1 5 3}$ & 0.966 & $\mathbf{2 . 3 4 1}$ & $\mathbf{1 . 8 2 7}$ & 0.749 & $\mathbf{1 . 5 8 3}$ & 0.327 & $\mathrm{n} / \mathrm{a}$ \\
$\mathrm{Fe}$ & 50000 & 3 & 0.578 & 0.723 & 0.843 & 0.531 & 0.665 & $\mathbf{1 . 1 4 9}$ & $\mathbf{1 . 3 5 3}$ & $\mathbf{n} / \mathbf{a}$ \\
$\mathrm{V}$ & 150 & 3 & 0.112 & 0.153 & 0.164 & $\mathbf{1 1 . 3 4 3}$ & 0.135 & 0.184 & 0.074 & $\mathrm{n} / \mathrm{a}$ \\
$\mathrm{Pb}$ & 16 & 4 & $\mathbf{1 . 0 7 8}$ & 0.710 & 0.734 & 0.883 & 0.420 & 0.397 & 0.316 & $\mathrm{n} / \mathrm{a}$ \\
$\mathrm{Pb}$ & 16 & 5 & $\mathbf{1 . 7 0 0}$ & $\mathrm{n} / \mathrm{a}$ & 0.676 & $\mathrm{n} / \mathrm{a}$ & 0.456 & $\mathrm{n} / \mathrm{a}$ & 0.344 & $\mathrm{n} / \mathrm{a}$ \\
$\mathrm{Pb}$ & 16 & 6 & $\mathbf{1 . 1 4 0}$ & $\mathrm{n} / \mathrm{a}$ & $\mathrm{n} / \mathrm{a}$ & $\mathrm{n} / \mathrm{a}$ & 0.590 & $\mathrm{n} / \mathrm{a}$ & $\mathrm{n} / \mathrm{a}$ & $\mathrm{n} / \mathrm{a}$ \\
\hline
\end{tabular}

Table 3. Enrichment factors of the mean concentration of elements present within sediments at each sample site.

\begin{tabular}{lrllllllll}
\hline Element & Clarke value & $\mathrm{S} 1$ & $\mathrm{~S} 2$ & $\mathrm{~S} 3(\mathrm{~T} 1)$ & $\mathrm{S} 3(\mathrm{~T} 2)$ & $\mathrm{S} 4$ & $\mathrm{~S} 5(\mathrm{~T} 1)$ & $\mathrm{S} 5(\mathrm{~T} 2)$ & $\mathrm{S} 6$ \\
\hline $\mathrm{Al}$ & 81300 & 0.158 & 0.189 & 0.183 & 0.175 & 0.129 & 0.135 & 0.130 & 0.265 \\
$\mathrm{As}$ & 5 & $\mathrm{NE}$ & $\mathrm{NE}$ & $\mathrm{NE}$ & $\mathrm{NE}$ & $\mathrm{NE}$ & 1.170 & 1.084 & 2.148 \\
$\mathrm{Ca}$ & 36300 & 0.149 & 0.106 & 0.135 & 0.102 & 0.105 & 0.109 & 0.093 & 0.198 \\
$\mathrm{Cr}$ & 200 & 0.171 & 0.241 & 0.272 & 0.228 & 0.143 & 0.298 & 0.307 & 0.543 \\
$\mathrm{Cu}$ & 70 & 1.051 & 0.967 & 1.074 & 1.034 & 0.695 & 0.570 & 0.740 & 1.295 \\
$\mathrm{Fe}$ & 50000 & $\mathrm{NE}$ & 0.250 & 0.283 & 0.290 & 0.293 & 0.296 & 0.285 & 0.552 \\
$\mathrm{Mg}$ & 20900 & 0.138 & 0.130 & 0.132 & 0.136 & 0.136 & 0.136 & 0.133 & 0.224 \\
$\mathrm{Mn}$ & 1000 & 0.810 & 0.758 & 0.836 & 0.831 & 0.795 & 0.805 & 0.748 & 1.840 \\
$\mathrm{Ni}$ & 80 & 0.046 & 0.085 & 0.201 & 0.102 & 0.218 & 0.094 & 0.085 & 0.268 \\
$\mathrm{P}$ & 1180 & 0.872 & 1.042 & 1.657 & 1.101 & 0.971 & 1.124 & 0.914 & 1.581 \\
$\mathrm{~Pb}$ & 16 & $\mathbf{8 . 2 9 4}$ & $\mathbf{7 . 2 6 9}$ & $\mathbf{9 . 0 3 7}$ & $\mathbf{6 . 1 4 9}$ & 3.994 & 3.464 & 4.303 & $\mathbf{1 6 . 8 3 3}$ \\
$\mathrm{V}$ & 150 & 0.582 & 0.528 & 0.594 & $\mathbf{6 . 7 9 4}$ & 0.583 & 0.549 & 0.575 & 0.768 \\
$\mathrm{Zn}$ & 132 & 0.978 & 0.851 & 1.861 & 0.730 & 0.347 & 1.354 & 0.898 & 1.190 \\
\hline $\mathrm{NE}$ & & & & & & & & &
\end{tabular}

NE: No enrichment.

$\mathrm{Fe}$ and $\mathrm{Pb}$ contamination is ubiquitous in the surface laminae across all six sites, with contamination factors being either border-line, moderate or of high contamination. Noteworthy are the contamination factors of $\mathrm{Pb}$ at sites $\mathrm{S} 2$ and $\mathrm{S} 3(\mathrm{~T} 1)$, indicating significant metal pollution. Sediment pollution resulting from high levels of zinc is shown to be less problematic across sites, with moderate contamination detected at S3(T1), and border-line contamination occuring at S5(T1).

Contamination factors for Fe show border-line contamination at site S3(T2), and moderate contamination at sites $\mathrm{S} 3(\mathrm{~T} 1)$ and $\mathrm{S} 5(\mathrm{~T} 2)$. $\mathrm{Pb}$ contamination is shown to be moderate across all sites except S4 and S5(T1), and S3(T2) and S5(T2), which signify low and high contamination respectively.
The 3rd lamina of the sediment cores shows low $\mathrm{Pb}$ contamination at $\mathrm{S} 5(\mathrm{~T} 2)$, border-line contamination at $\mathrm{S} 2$ and $\mathrm{S} 4$ and moderate contamination across the remaining sites. Fe contamination is moderate at sites S5(T1) and S5(T2), moderate at site $\mathrm{S} 3(\mathrm{~T} 1)$, and low in the remaining sites.

In the 4th, 5th and 6th laminae of sediment cores, $\mathrm{Pb}$ is the only metal showing border-line moderate to high contamination levels.

In the 4th lamina, there is moderate $\mathrm{Pb}$ contamination at site $\mathrm{S} 1$, border-line moderate contamination at site $\mathrm{S} 3(\mathrm{~T} 2)$ and low contamination in the remaining sites. $\mathrm{Pb}$ contamination in the 5th layer is calculated to be moderate at $\mathrm{S} 1$, low at sites $\mathrm{S} 3(\mathrm{~T} 1), \mathrm{S} 4$ and $\mathrm{S} 5(\mathrm{~T} 2)$, and none at the remaining sites. Likewise, in the 6th lamina of cores, $\mathrm{Pb}$ contamination is moderate only 
Table 4. Enrichment factor of particular elements present within laminae 1, 2 and 3 of sediment cores at each sample site.

\begin{tabular}{|c|c|c|c|c|c|c|c|c|c|c|}
\hline Ion & Clarke value & $\mathrm{L}$ & $\mathrm{S} 1$ & $\mathrm{~S} 2$ & $\mathrm{~S} 3(\mathrm{~T} 1)$ & $\mathrm{S} 3(\mathrm{~T} 2)$ & $\mathrm{S} 4$ & $\mathrm{~S} 5(\mathrm{~T} 1)$ & $\mathrm{S} 5(\mathrm{~T} 2)$ & S6 \\
\hline $\mathrm{Cu}$ & 70 & 1 & 4.190 & 3.701 & 4.225 & 3.430 & 3.214 & 2.636 & 3.445 & 2.323 \\
\hline $\mathrm{Pb}$ & 16 & 1 & 27.371 & 41.088 & 45.190 & 19.057 & 18.002 & 16.069 & 16.565 & 37.974 \\
\hline $\mathrm{Zn}$ & 132 & 1 & 5.976 & 7.106 & 11.320 & 3.202 & 2.489 & 8.685 & 4.112 & 2.880 \\
\hline $\mathrm{Ni}$ & 80 & 1 & 0.352 & 0.787 & 0.876 & 0.591 & 0.141 & 0.598 & 0.355 & 0.641 \\
\hline $\mathrm{Cr}$ & 200 & 1 & 1.018 & 1.516 & 1.433 & 1.222 & 0.954 & 1.344 & 1.363 & 1.011 \\
\hline As & 5 & 1 & $\mathrm{NE}$ & $\mathrm{NE}$ & $\mathrm{NE}$ & $\mathrm{NE}$ & $\mathrm{NE}$ & 4.005 & 2.911 & 3.124 \\
\hline $\mathrm{V}$ & 150 & 1 & 1.912 & 1.468 & 1.895 & 2.209 & 1.994 & 1.884 & 1.947 & 1.306 \\
\hline $\mathrm{P}$ & 1180 & 1 & 3.866 & 6.015 & 8.710 & 4.195 & 4.477 & 5.104 & 3.484 & 2.732 \\
\hline Mn & 1000 & 1 & 3.483 & 4.788 & 3.938 & 3.122 & 4.378 & 3.878 & 2.823 & 2.462 \\
\hline $\mathrm{Cu}$ & 70 & 2 & 3.764 & 3.063 & 4.958 & 4.208 & 3.568 & 1.683 & 2.865 & 1.631 \\
\hline $\mathrm{Pb}$ & 16 & 2 & 31.547 & 16.204 & 35.689 & 23.191 & 14.841 & 7.991 & 23.035 & 34.363 \\
\hline $\mathrm{Zn}$ & 132 & 2 & 1.599 & 9.850 & 4.555 & 5.614 & 2.425 & 0.900 & 5.614 & 2.425 \\
\hline $\mathrm{Ni}$ & 80 & 2 & $\mathrm{NE}$ & $\mathrm{NE}$ & 1.799 & 0.611 & $\mathrm{NE}$ & $\mathrm{NE}$ & 0.658 & 0.589 \\
\hline $\mathrm{Cr}$ & 200 & 2 & 0.172 & 0.473 & 1.631 & 1.096 & $\mathrm{NE}$ & 0.646 & 1.408 & 1.001 \\
\hline As & 5 & 2 & $\mathrm{NE}$ & $\mathrm{NE}$ & $\mathrm{NE}$ & $\mathrm{NE}$ & $\mathrm{NE}$ & 3.928 & 2.649 & 6.127 \\
\hline $\mathrm{V}$ & 150 & 2 & 2.153 & 2.059 & 2.139 & 1.836 & 2.241 & 1.839 & 1.815 & 1.285 \\
\hline $\mathrm{P}$ & 1180 & 2 & 2.627 & 2.298 & 9.652 & 5.577 & 3.606 & 2.579 & 3.964 & 2.342 \\
\hline $\mathrm{Mn}$ & 1000 & 2 & 2.492 & 1.644 & 5.616 & 3.826 & 1.713 & 1.506 & 4.803 & 3.285 \\
\hline $\mathrm{Cu}$ & 70 & 3 & 3.177 & 2.800 & 3.409 & 4.476 & 2.460 & 1.980 & 2.232 & $n / a$ \\
\hline $\mathrm{Pb}$ & 16 & 3 & 19.950 & 13.364 & 27.778 & 34.412 & 11.251 & 13.779 & 10.550 & $n / a$ \\
\hline $\mathrm{Zn}$ & 132 & 3 & 1.468 & 0.542 & 4.485 & 3.977 & 0.212 & 5.089 & 0.712 & $n / a$ \\
\hline $\mathrm{Ni}$ & 80 & 3 & $N E$ & $N E$ & 0.563 & $N E$ & $N E$ & 0.504 & $N E$ & $n / a$ \\
\hline $\mathrm{Cr}$ & 200 & 3 & 0.265 & 0.601 & 1.078 & 0.834 & 0.550 & 0.693 & 0.781 & $n / a$ \\
\hline As & 5 & 3 & $N E$ & $N E$ & NE & $N E$ & $N E$ & 2.661 & 5.959 & $n / a$ \\
\hline $\mathrm{V}$ & 150 & 3 & 1.946 & 2.114 & 1.951 & 213.68 & 2.029 & 1.598 & 2.379 & $n / a$ \\
\hline $\mathrm{P}$ & 1180 & 3 & 2.235 & 2.325 & 3.581 & 3.579 & 3.289 & 4.002 & 2.710 & $n / a$ \\
\hline Mn & 1000 & 3 & 2.522 & 1.427 & 1.880 & 7.607 & 1.700 & 3.746 & 0.905 & $n / a$ \\
\hline
\end{tabular}

at $\mathrm{S} 1$, low at $\mathrm{S} 4$ and none in the remaining sites.

From table 3 , it can be seen that $\mathrm{Ca}, \mathrm{Mn}, \mathrm{P}$, $\mathrm{Pb}, \mathrm{V}$ and $\mathrm{Zn}$ are likely to have been derived from anthropogenic sources. Enrichment factors for $\mathrm{As}, \mathrm{Mn}$ and $\mathrm{P}$ at site S6 indicate possible anthropogenic sources, while the enrichment factor for $\mathrm{Pb}$ at site $\mathrm{S} 6$ is more conclusive. The data also show a possibility of anthropogenic input of $\mathrm{P}$ and $\mathrm{Zn}$ at site S3(T1), while all other detected elements for this site were naturally derived. Further, the enrichment factors for $\mathrm{Pb}$ across all sites imply either possible anthropogenic input or definite contamination. This is consistent with contamination factor data displayed in table 1, which shows border-line moderate or moderate $\mathrm{Pb}$ contamination across the sample sites. Results of ANOVA showed high variance for $\mathrm{Pb}$ (18.67) as well as $\mathrm{V}$ (4.81). The latter reflective of the anomalous high $\mathrm{V}$ measured at site $3(\mathrm{~T} 2)$.

Tables 4 and 5 display the enrichment factors determined using actual concentrations of metals detected within each lamina of sediment cores.

In tables 4 and 5 , it can be seen that apart from the enrichment factors established for $\mathrm{Ni}$ across all sites, which imply metal input from natural origins, all other metals indicate some degree of enrichment. Similar to Ni, Cr is naturally derived at all sites with the exception of site S2, in which concentrations are potentially anthropogenically derived. Apart from $\mathrm{Ni}$ and $\mathrm{Cr}$, it is evident that all metals detected within the 1st layer of sediment cores have possible anthropogenic origins; however, the enrichment factors established for $\mathrm{Pb}$ across all sites, V at sites $\mathrm{S} 1-\mathrm{S} 3(\mathrm{~T} 1)$ and $\mathrm{S} 5(\mathrm{~T} 1)$ and $\mathrm{P}$ at site $\mathrm{S} 2-\mathrm{S} 3(\mathrm{~T} 1)$ and $\mathrm{S} 5(\mathrm{~T} 1)$, which show definite enrichment are of particular concern. It is also noteworthy that As concentrations were undetected at sites S1-S4, but were found to be anthropogenically enriched at sites S5(T1)-S6 wherever detected.

The enrichment factors calculated for the 2nd lamina of all sediment cores show similar trends to 
Table 5. Enrichment factor of particular elements present within lamina 4, 5 and 6 of sediment cores at each sample site.

\begin{tabular}{|c|c|c|c|c|c|c|c|c|c|c|}
\hline Ion & Clarke value & $\mathrm{L}$ & $\mathrm{S} 1$ & $\mathrm{~S} 2$ & $\mathrm{~S} 3(\mathrm{~T} 1)$ & $\mathrm{S} 3(\mathrm{~T} 2)$ & $\mathrm{S} 4$ & $\mathrm{~S} 5(\mathrm{~T} 1)$ & $\mathrm{S} 5(\mathrm{~T} 2)$ & $\mathrm{S} 6$ \\
\hline $\mathrm{Cu}$ & 70 & 4 & 4.596 & 5.907 & 2.904 & 3.653 & 1.445 & 1.420 & 1.755 & $\mathrm{n} / \mathrm{a}$ \\
\hline $\mathrm{Pb}$ & 16 & 4 & 30.172 & 28.75 & 12.19 & 22.09 & 8.838 & 8.047 & 7.781 & $\mathrm{n} / \mathrm{a}$ \\
\hline $\mathrm{Zn}$ & 132 & 4 & 1.050 & $\mathrm{NE}$ & 0.843 & $\mathrm{NE}$ & 0.464 & 1.214 & 0.463 & $\mathrm{n} / \mathrm{a}$ \\
\hline $\mathrm{Ni}$ & 80 & 4 & $\mathrm{NE}$ & $\mathrm{NE}$ & 0.150 & $\mathrm{NE}$ & $\mathrm{NE}$ & $\mathrm{NE}$ & $\mathrm{NE}$ & $\mathrm{n} / \mathrm{a}$ \\
\hline $\mathrm{Cr}$ & 200 & 4 & $\mathrm{NE}$ & $\mathrm{NE}$ & 0.237 & $\mathrm{NE}$ & 0.701 & 0.753 & 0.589 & $\mathrm{n} / \mathrm{a}$ \\
\hline As & 5 & 4 & $\mathrm{NE}$ & $\mathrm{NE}$ & $\mathrm{NE}$ & $\mathrm{NE}$ & 5.307 & 4.635 & 5.266 & $\mathrm{n} / \mathrm{a}$ \\
\hline $\mathrm{V}$ & 150 & 4 & 2.388 & 2.843 & 1.992 & 2.368 & 1.927 & 1.004 & 2.154 & $\mathrm{n} / \mathrm{a}$ \\
\hline $\mathrm{P}$ & 1180 & 4 & 2.573 & 2.471 & 2.537 & 2.593 & 2.289 & 2.867 & 2.245 & $\mathrm{n} / \mathrm{a}$ \\
\hline $\mathrm{Mn}$ & 1000 & 4 & 3.157 & 0.908 & 0.817 & 0.494 & 2.133 & 1.340 & 1.028 & $\mathrm{n} / \mathrm{a}$ \\
\hline $\mathrm{Cu}$ & 70 & 5 & 1.081 & $\mathrm{n} / \mathrm{a}$ & 3.331 & $\mathrm{n} / \mathrm{a}$ & 1.327 & $\mathrm{n} / \mathrm{a}$ & 0.896 & $\mathrm{n} / \mathrm{a}$ \\
\hline $\mathrm{Pb}$ & 16 & 5 & 28.084 & $\mathrm{n} / \mathrm{a}$ & 20.43 & $\mathrm{n} / \mathrm{a}$ & 9.352 & $\mathrm{n} / \mathrm{a}$ & 7.928 & $\mathrm{n} / \mathrm{a}$ \\
\hline $\mathrm{Zn}$ & 132 & 5 & 1.114 & $\mathrm{n} / \mathrm{a}$ & $\mathrm{NE}$ & $\mathrm{n} / \mathrm{a}$ & 0.369 & $\mathrm{n} / \mathrm{a}$ & 0.802 & $\mathrm{n} / \mathrm{a}$ \\
\hline $\mathrm{Ni}$ & 80 & 5 & $\mathrm{NE}$ & $\mathrm{n} / \mathrm{a}$ & $\mathrm{NE}$ & $\mathrm{n} / \mathrm{a}$ & $\mathrm{NE}$ & $\mathrm{n} / \mathrm{a}$ & $\mathrm{NE}$ & $\mathrm{n} / \mathrm{a}$ \\
\hline $\mathrm{Cr}$ & 200 & 5 & 0.299 & $\mathrm{n} / \mathrm{a}$ & $\mathrm{NE}$ & $\mathrm{n} / \mathrm{a}$ & 0.702 & $\mathrm{n} / \mathrm{a}$ & 0.681 & $\mathrm{n} / \mathrm{a}$ \\
\hline As & 5 & 5 & $\mathrm{NE}$ & $\mathrm{n} / \mathrm{a}$ & $\mathrm{NE}$ & $\mathrm{n} / \mathrm{a}$ & 5.011 & $\mathrm{n} / \mathrm{a}$ & 5.280 & $\mathrm{n} / \mathrm{a}$ \\
\hline $\mathrm{V}$ & 150 & 5 & 2.057 & $\mathrm{n} / \mathrm{a}$ & 2.455 & $\mathrm{n} / \mathrm{a}$ & 2.006 & $\mathrm{n} / \mathrm{a}$ & 2.239 & $\mathrm{n} / \mathrm{a}$ \\
\hline $\mathrm{P}$ & 1180 & 5 & 2.338 & $\mathrm{n} / \mathrm{a}$ & 2.255 & $\mathrm{n} / \mathrm{a}$ & 2.135 & $\mathrm{n} / \mathrm{a}$ & 2.716 & $\mathrm{n} / \mathrm{a}$ \\
\hline $\mathrm{Mn}$ & 1000 & 5 & 2.138 & $\mathrm{n} / \mathrm{a}$ & 0.954 & $\mathrm{n} / \mathrm{a}$ & 0.859 & $\mathrm{n} / \mathrm{a}$ & 0.692 & $\mathrm{n} / \mathrm{a}$ \\
\hline $\mathrm{Cu}$ & 70 & 6 & 4.316 & $\mathrm{n} / \mathrm{a}$ & $\mathrm{n} / \mathrm{a}$ & $\mathrm{n} / \mathrm{a}$ & 0.771 & $\mathrm{n} / \mathrm{a}$ & $\mathrm{n} / \mathrm{a}$ & $\mathrm{n} / \mathrm{a}$ \\
\hline $\mathrm{Pb}$ & 16 & 6 & 26.111 & $\mathrm{n} / \mathrm{a}$ & $\mathrm{n} / \mathrm{a}$ & $\mathrm{n} / \mathrm{a}$ & 12.57 & $\mathrm{n} / \mathrm{a}$ & $\mathrm{n} / \mathrm{a}$ & $\mathrm{n} / \mathrm{a}$ \\
\hline $\mathrm{Zn}$ & 132 & 6 & 1.245 & $\mathrm{n} / \mathrm{a}$ & $\mathrm{n} / \mathrm{a}$ & $\mathrm{n} / \mathrm{a}$ & 0.759 & $\mathrm{n} / \mathrm{a}$ & $\mathrm{n} / \mathrm{a}$ & $\mathrm{n} / \mathrm{a}$ \\
\hline $\mathrm{Ni}$ & 80 & 6 & $\mathrm{NE}$ & $\mathrm{n} / \mathrm{a}$ & $\mathrm{n} / \mathrm{a}$ & $\mathrm{n} / \mathrm{a}$ & $\mathrm{NE}$ & $\mathrm{n} / \mathrm{a}$ & $\mathrm{n} / \mathrm{a}$ & $\mathrm{n} / \mathrm{a}$ \\
\hline $\mathrm{Cr}$ & 200 & 6 & 0.159 & $\mathrm{n} / \mathrm{a}$ & $\mathrm{n} / \mathrm{a}$ & $\mathrm{n} / \mathrm{a}$ & 0.710 & $\mathrm{n} / \mathrm{a}$ & $\mathrm{n} / \mathrm{a}$ & $\mathrm{n} / \mathrm{a}$ \\
\hline As & 5 & 6 & $\mathrm{NE}$ & $\mathrm{n} / \mathrm{a}$ & $\mathrm{n} / \mathrm{a}$ & $\mathrm{n} / \mathrm{a}$ & 3.393 & $\mathrm{n} / \mathrm{a}$ & $\mathrm{n} / \mathrm{a}$ & $\mathrm{n} / \mathrm{a}$ \\
\hline $\mathrm{V}$ & 150 & 6 & 2.213 & $\mathrm{n} / \mathrm{a}$ & $\mathrm{n} / \mathrm{a}$ & $\mathrm{n} / \mathrm{a}$ & 1.775 & $\mathrm{n} / \mathrm{a}$ & $\mathrm{n} / \mathrm{a}$ & $\mathrm{n} / \mathrm{a}$ \\
\hline $\mathrm{P}$ & 1180 & 6 & 2.589 & $\mathrm{n} / \mathrm{a}$ & $\mathrm{n} / \mathrm{a}$ & $\mathrm{n} / \mathrm{a}$ & 1.730 & $\mathrm{n} / \mathrm{a}$ & $\mathrm{n} / \mathrm{a}$ & $\mathrm{n} / \mathrm{a}$ \\
\hline $\mathrm{Mn}$ & 1000 & 6 & 2.227 & $\mathrm{n} / \mathrm{a}$ & $\mathrm{n} / \mathrm{a}$ & $\mathrm{n} / \mathrm{a}$ & 1.536 & $\mathrm{n} / \mathrm{a}$ & $\mathrm{n} / \mathrm{a}$ & $\mathrm{n} / \mathrm{a}$ \\
\hline
\end{tabular}

those of the 1st lamina such that $\mathrm{Pb}$ contamination occurs across all sites, and all metals except $\mathrm{Ni}$ and $\mathrm{Cr}$ indicate possible anthropogenic input or enrichment in each core. Metal contamination within lamina 2 results from the input of $\mathrm{Zn}$ at sites S2, S3(T2) and S5(T2); the input of $\mathrm{P}$ at sites $\mathrm{S} 3(\mathrm{~T} 1)-\mathrm{S} 3(\mathrm{~T} 2)$ and the addition of $\mathrm{As}$ and $\mathrm{Mn}$ at sites $\mathrm{S} 6$ and $\mathrm{S} 3(\mathrm{~T} 1)$, respectively.

The enrichment factors calculated for the 3rd and 4th laminae of sediment cores show $\mathrm{Pb}$ contamination across all sites. Unlike in the 3rd lamina, however, $\mathrm{Zn}$ concentrations in the 4th lamina are also of natural origin across all sample sites. Furthermore, As is also shown to be possibly anthropogenically enriched at site S5(T1) in the 3rd and 4th laminae, at site $\mathrm{S} 4$ in the 4th lamina and at site S5(T2) in the 3rd lamina. Signs of enrichment to note in the 3rd lamina result from the input of $\mathrm{Zn}$ at site $\mathrm{S} 5(\mathrm{~T} 1)$, As at site $\mathrm{S} 5(\mathrm{~T} 2)$, and $\mathrm{V}$ and $\mathrm{Mn}$ at site $\mathrm{S} 3(\mathrm{~T} 2)$.
$\mathrm{Cu}$ enrichment occurs in the 4th lamina at site S2.

Cores collected from sites S1, S3(T1), S4 and S5(T2) comprise a 5th lamina, but the consistent trend of high $\mathrm{Pb}$ enrichment across sample sites within preceding sediment layers is displayed in this laminae as well. Nickel was undetected within this layer across all sample sites, and the enrichment factors for all other elements at each site indicate either natural origins with possibly some minor anthropogenic enrichment.

Amongst the sediment cores of interest in this study, only those collected at sites S1 and S4 contain a 6th lamina. Similar to data obtained for the 5th lamina, Ni concentrations were undetected across all sites and $\mathrm{Pb}$ values indicate contamination at both sites. Enrichment factors calculated for the remaining metals at each site indicate that the concentrations are either naturally derived or possibly sourced from anthropogenic activities. 


\section{Scree Plot of Eigen Values for Components of Sites Analysed}

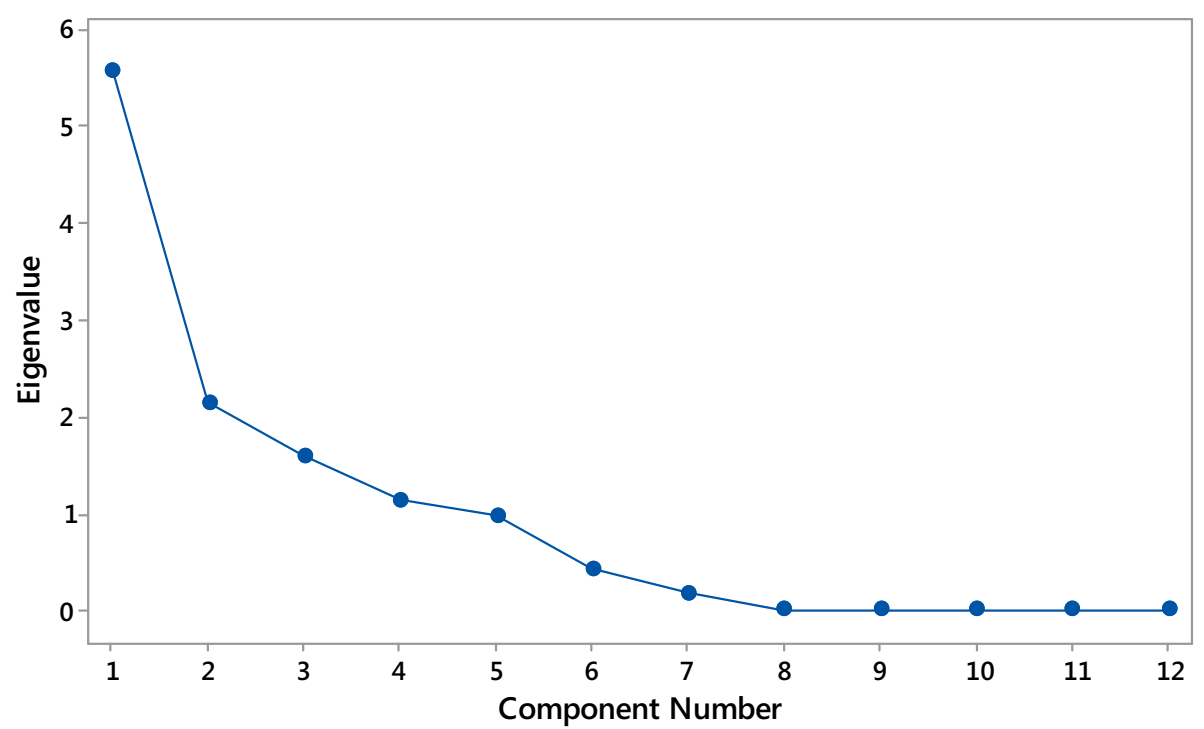

Figure 4. A Scree Plot indicating eigenvalues for components contributing to pollution loading using the MiniTab17 Software Programme ${ }^{\circledR}$.

\subsection{Statistical analysis}

\subsubsection{ANOVA}

Results of ANOVA confirm the above. Highest three variances for each of the lamina are as follows: $\mathrm{L} 1: \mathrm{Pb}(145.54)>\mathrm{Zn}(9.93)>\mathrm{P}$ (3.46); L2: $\mathrm{Pb}(100.03)>\mathrm{Zn}(8.57)>$ As (3.09); L3: V (6401.09) > Pb (84.23) > As (5.44); L4: $\mathrm{Pb}$ (98.70) $>\mathrm{Cu}(2.97)>\mathrm{Mn}(0.86)$; L5: $\mathrm{Pb}(91.40)>\mathrm{Cu}$ (1.27) > Mn (0.44) and L6: $\mathrm{Pb}(91.68)>\mathrm{Cu}(6.28)$ $>\mathrm{P}(0.34)$.

\subsubsection{Principal component analysis (PCA)}

PCA has been implemented to gain a proper understanding of the contribution of elements to contamination and subsequent pollution loading at each site. The calculated Eigen values shown in figure 4, reveal a $46.4 \%$ variance contributed from elements associated to component 1 (shown in table 6) which include elements $\mathrm{Al}, \mathrm{Ca}, \mathrm{Cr}, \mathrm{Cu}$, $\mathrm{Fe}, \mathrm{Mg}, \mathrm{Mn}$ and $\mathrm{Zn}$. In addition, a $17.8 \%$ variance was contributed from elements associated to component 2, which include $\mathrm{Al}, \mathrm{Cu}$ and $\mathrm{Fe}$ only. A total of $64.2 \%$ variation in elements contributing to the contamination was accounted by components 1 and 2 as shown in table 6 , which is an acceptable representation of the contribution to pollution loading from the elements at each site.
Table 6. Element loadings of principal components 1 and 2.

\begin{tabular}{lcc}
\hline Variables & $\begin{array}{c}\text { Principal } \\
\text { component } 1\end{array}$ & $\begin{array}{c}\text { Principal } \\
\text { component 2 }\end{array}$ \\
\hline $\mathrm{Al}$ & 0.328853 & 0.303076 \\
$\mathrm{Ca}$ & 0.316976 & \\
$\mathrm{Cr}$ & 0.326331 & \\
$\mathrm{Cu}$ & 0.195742 & 0.537873 \\
$\mathrm{Fe}$ & 0.328873 & -0.392949 \\
$\mathrm{Mg}$ & 0.345046 & \\
$\mathrm{Mn}$ & 0.364673 & \\
$\mathrm{Ni}$ & & \\
$\mathrm{P}$ & & \\
$\mathrm{Zn}$ & 0.346304 & \\
\hline
\end{tabular}

The score plot in figure 5 indicates variation in the contribution of contaminating metals at all sites. This has been observed from the wide distribution of sites as shown in the score plot of figure 5. Sites S6 and S3 have high values in component 1 ( $\mathrm{Al}, \mathrm{Ca}, \mathrm{Cr}, \mathrm{Cu}, \mathrm{Fe}, \mathrm{Mg}, \mathrm{Mn}$ and $\mathrm{Zn}$ ), while $\mathrm{S} 1, \mathrm{~S} 4$ and $\mathrm{S} 5$ have low values in component 1 as shown in the score plot of figure 5. Sites S2, S3(T2) and S5(T1) are shown to have average values of component 1 (figure 5).

$\mathrm{S} 1, \mathrm{~S} 2$, and $\mathrm{S} 3$ have high values in component 2 as shown in figure 5 while $\mathrm{S} 4$, S5(T1), and $\mathrm{S} 5(\mathrm{~T} 2)$ have low values of component 2 which include the elements $\mathrm{Al}, \mathrm{Cu}$ and $\mathrm{Fe}$. 


\section{Score Plot of Sites with Contaminant Component Loadings}

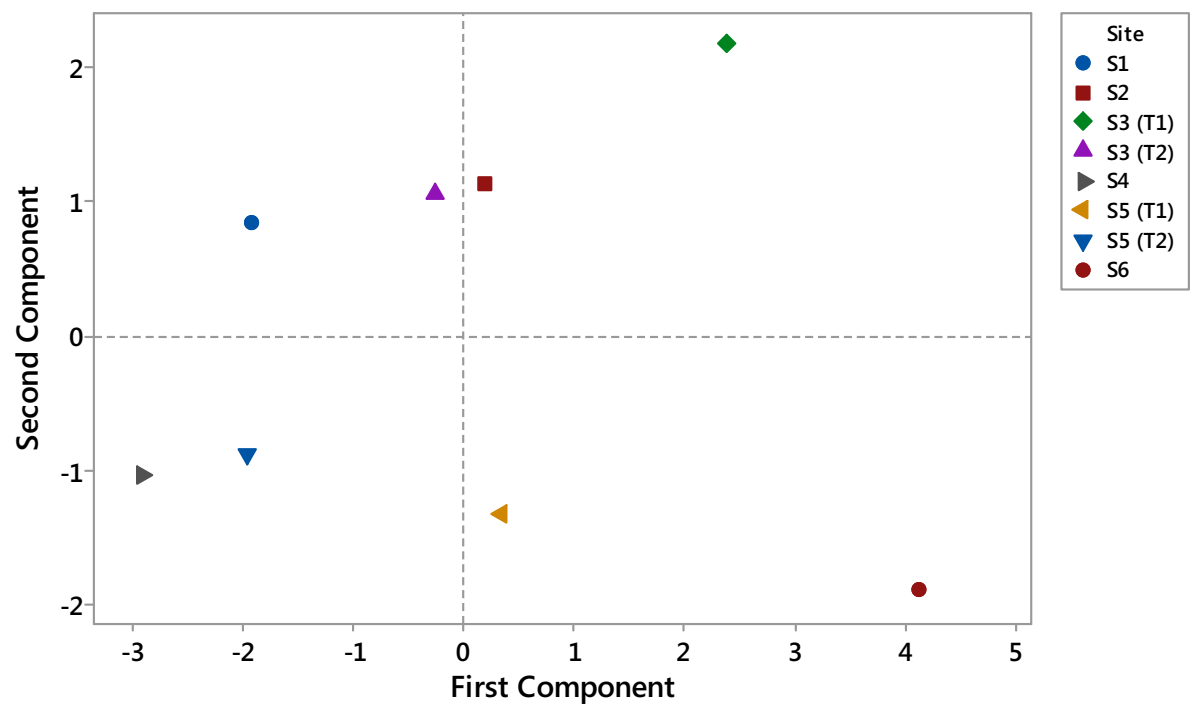

Figure 5. Score plots showing component loadings at different sites using the MiniTab17 Software Programme ${ }^{\circledR}$.

\section{Conclusion}

Overall, the tabulated data above displays a general decreasing trend of metal contamination with each subsequent lamina (Wuana and Okieimen 2011). The highest levels of anthropogenic contamination have been detected within the first three layers of sediment cores such that moderate to high contamination levels are most widespread in the 1st lamina and decreases with each of the following laminae. Of particular concern is the high concentration of $\mathrm{Pb}$ across the wetlands of interest, particularly within the first three layers of sediment, showing significant contamination levels at $\mathrm{S} 2, \mathrm{~S} 3(\mathrm{~T} 1)$ and $\mathrm{S} 5(\mathrm{~T} 2)$ in the first two laminae of sediment cores. The prevalence of moderate and high contamination factors for $\mathrm{Pb}$ is concomitant to the dominance of fine-particled sediment and high percentages of organic matter within the first three laminae of sediment cores. Enrichment of other elements analysed for displays no uniform pattern but contamination of different elements at varying laminae and wetland site is present. It can therefore be concluded that anthropogenic input of metals into the Lower uMngeni wetlands had occured in recent times, persists to the present and possible excerbation of the situation is likely have given the relative fast pace of development in the vicinity of the wetlands and in the hinterland of the catchment. Given this situation, it is of utmost importance that the local municipality develops and implements proper management measures that are focused on curtailing the current pollution levels and so minimising the risk of future degradation.

\section{Acknowledgements}

We thank the National Research Fund (NRF), South Africa for the financial support for the study and the valuable comment from the reviewers.

\section{References}

Ahmed W, Atsushi K, Mohamed S M B, Hamed B D, Hiroko I, Maki T and Mohamed K 2015 Effects of metal pollution on sediments in a highly saline aquatic ecosystem: Case of the Moknine Continental Sebkha (Eastern Tunisia); Bull. Environ. Contam. Toxicol. 94 511-518, https://doi.org/ 10.1007/s00128-015-1469-9.

Ayeni O O, Ndakidemi P A, Snyman R G and Odendaal J P 2010 Chemical, biological and physiological indicators of metal pollution in wetlands; Sci. Res. Essays 5(15) 1938-1949.

Bhuiyan M A H, Parvez L, Islam M A, Dampare, S B and Suzuki S 2010 Heavy metal pollution of coal mine-affected agricultural soils in the northern part of Bangladesh; $J$. Haz. Mat. 173(1-3) 384-392.

Brijlal N 2005 The environmental and health status of the uMngeni Estuary in KwaZulu-Natal, South Africa, Unpublished MSc Dissertation, University of KwaZuluNatal, Durban, South Africa.

Cobelo-García A and Prego R 2003 Heavy metal sedimentary record in a Galician Ria (NW Spain): Background values and recent contamination; Mar. Pollut. Bull. 46(10) 1253-1262.

Cobelo-García A and Prego R 2004 Influence of point sources on trace metal contamination and distribution in a semi-enclosed industrial embayment: The Ferrol 
Ria (NW Spain); Estuar. Coast. Shelf Sci. 60(4) 695703.

Cooper J A G 1993 Sedimentation in a river dominated estuary; Sedimentology, 40, Catchment and Catchment Environment Programme, CSIR, Kwa-Zulu Natal, pp. 980-982.

Dickens C, Kotze D, Mashigo S, Mackay H and Graham M 2003 Guidelines for integrating the protection, conservation and management of wetlands into Catchment Management Planning; Water Research Commission, Report No. TT 220/03.

Gren I, Folke C, Turner K and Bateman I 1994 Primary and secondary values of wetland ecosystems; Environ. Resour. Econ. 4 55-74.

Harikumar P S, Nasir U P and Mujeebu R M P 2009 Distribution of heavy metals in the core sediments of a tropical wetland system; Int. J. Environ. Sci. Technol. 6(2) 225232

Harikumar P S and Jisha T S 2010 Distribution pattern of trace metal pollutants in the sediments of an urban wetland in the southwest coast of India; Int. J. Eng. Sci. Technol. 2(5) 840-850.

Karlen D L, Mausbach M J, Doran J W, Cline R G, Harris R F and Schuman G E 1997 Soil quality: A concept, definition, and framework for evaluation; Soil Sci. Soc. Am. J. 61(1) 4-10.

Khechfe A I 1997 Benthic microalgae as bio-indicators of sediment quality in San Francisco Bay; MSc Dissertation, Paper 1452.

Kotze D C 2000 Wetlands and Water Quality Enhancement, University of Natal, Durban.

Martínez-Carballo E, González-Barreiro C, Sitka A, Kreuzinger N, Scharf S and Gans O 2007 Determination of selected quaternary ammonium compounds by liquid chromatography with mass spectrometry: Part II. Application to sediment and sludge samples in Austria; Environ. Pollut. 146(2) 543-547.

Martinez J, Llamas J, de Miguel E, Rey J and Hildago M C 2007 Determination of the geochemical background in a metal mining site: Example of the mining district of Linares (South Spain); J. Geochem. Explor. 94 19-29.

Nabulo G, Origa H O, Nasinyama G W and Cole D 2008 Assessment of $\mathrm{Zn}, \mathrm{Cu}, \mathrm{Pb}$ and $\mathrm{Ni}$ contamination in wetland soils and plants in the Lake Victoria Basin; Int. J. Environ. Sci. Technol. 5(1) 65-74.

Niu Y, Pang Y and Yu H 2015 Assessment of heavy metal pollution in sediments of inflow rivers toLake Taihu,
China; Bull. Environ. Contam. Toxicol. 95(5) 618623.

Nomaan M H, Pawar R S and Panaskar DB 2012 Assessment of heavy metals in sediments from coastal Al-Hodiedah Governorate, Yemen; Uni. J. Environ. Res. Tech. 2(3) $168-173$.

Rana V, Maiti S K and Jagadevan S 2016 Ecological risk assessment of metals contamination in the sediments of natural urban wetlands in dry tropical climate; Bull. Environ. Contam. Toxicol. 97 407, https://doi.org/10.1007/ s00128-016-1885-5.

Rural Development Services 2002 Agricultural Assessment of the uMngeni Municipality, Durban, KwaZulu Natal.

Sheoran A S and Sheoran V 2006 Heavy metal removal mechanism of acid mine drainage in wetlands: A critical review; Miner. Eng. 19(2) 105-116.

Soares H M V M, Boaventura R A R, Machado A A S C and Steves da Silva J C G 1999 Sediments as monitors of heavy metal contamination in the Ave River Basin (Portugal): multivariate analysis of data; Environ. Pollut. 105(3) 311-323.

Skoog D A and West D M 1982 Fundamentals of analytical chemistry; Saunders College Publishing, Philadelphia, $364 \mathrm{p}$.

South Durban; Community Environmental Alliance 2011 Feeling the Heat in Durban; Capital. Nat. Soc. 22(4) 50-73.

Sukdeo P 2010 A study of the natural and anthropogenic impacts on the sediment and water quality of the middle and lower Mvoti River System; MSc Dissertation, University of KwaZulu-Natal, Durban.

Van der Zel D W 1975 uMngeni river catchment analysis; Water $S A$ 1(2) 70-75.

Vitousek P M, Mooney H A, Lubchenco J and Melillo J M 1997 Human alteration of the global nitrogen cycle: Sources and consequences; Ecol. Appl. 7(3) 494499.

Walmsley R D 1992 The role of multidisciplinary research programmes in the management of water resources; Water $S A$ 18(3) 195-201.

Water Research Commission 2002 State of Rivers Report: uMngeni River and neighboring rivers and streams; Department of Water Affairs and Forestry, Pretoria.

Wuana R A and Okieimen F E 2011 Heavy metals in contaminated soils: A review of sources, chemistry, risks and best available strategies for remediation; ISRN Ecol., Article ID 402647, 1-20. 